\title{
DINAMIKA GERAKAN SOSIAL DALAM MENENTANG PEMBUANGAN LIMBAH PABRIK KULIT
}

Studi Deskriptif di Kecamatan Sukun, Kelurahan Ciptomulyo Kota Malang, Jawa Timur

\author{
Awan Setia Dharmawan \\ Universitas Muhammadiyah Malang \\ setiadharmawan@umm.ac.id
}

\begin{abstract}
Abstrak: Studi ini merumuskan masalah tentang bagaimana dinamika gerakan dalam masyarakat Kelurahan Ciptomulyo dengan tujuan mendeskripsikan dinamika gerakan sosial dan faktor yang menyebabkannya. Penelitian ini menggunakan metode kualitatif dengan pendekatan deskriptif dan lokasi penelitian di Kelurahan Sukun, Kecamatan Ciptomulyo, Kota Malang. Subyek penelitian ditentukan menggunkan teknik purposive sampling. Pengumpulan data dilakukan dengan teknik observasi, wawancara, dan dokumentasi. Dari hasil penelitian dapat diketahui bahwa, dinamika gerakan lingkungan tersebut terjadi dalam 2 tahap; pertama pada tahun 2001 dan kedua pada tahun 2014. Gerakan pertama menjadi penyebab dinamika Gerakan sosial. Hal tersebut dipengaruhi oleh indikasi pemimpin gerakan tersebut menerima suap, anggota direkrut menjadi karyawan perusahaan, dan beberapa warga RW 2 diangkat juga menjadi pekerja di dalam perusahaan. Sedangkan pada tahun 2014, dinamika gerakan dipengaruhi oleh adanya tekanan dari internal gerakan dan dipengaruhi oleh pihak luar.
\end{abstract}

[Abstract: This study formulates the problem of how the dynamics of movement in the Kelurahan Ciptomulyo. The study uses a qualitative method with a descriptive approach and the research location in Kelurahan Sukun, Ciptomulyo Sub-district, Malang City. Purposive sampling technique was used to determine the subjects. Data were collected through observation, interview, and documentation. The research results are described that the dynamics of the environmental movement occur in 2 stages; first in 2001 and second in 2014. The first movement was the cause of the social movement. This was influenced by indications that the leader of the movement accepted bribes; members were recruited as employees of the company, and several residents of RW 2 were appointed as workers in the company. Whereas in 2014, the dynamics of the movement were influenced by internal pressures and influenced by outsiders.]

Kata kunci: Pembuangan Limbah, Dinamika, Gerakan Sosial 


\section{A. Pendahuluan}

Keadaan lingkungan yang semakin hari semakin mendapatkan ancaman dari ulah tangan manusia juga terus menerus dirasakan oleh kita, seperti keadaan sungai yang mayoritas masih menjadi alternatif bagi setiap perusahaan untuk membuang limbah hasil produksinya secara langsung tanpa harus di olah lagi. Hal ini menjadi permasalahan lingkungan yang sampai saat ini kita hadapi sebagai umat manusia yang hidup tidak lepas akan kausalitas dipengaruhi dan mempengaruhi, seperti yang disampaikan pada penelitian terkait keberlangsungan hutan di Nordic terkait dengan sustainable risk dan environmental risk (Andersson \& Westholm, 2019)

Hal ini tidak lepas dari munculnya revolusi industri yang terjadi di Inggris dan Prancis sekitar abad ke-18, yang berawal dengan digantinya tenaga manusia dan hewan dengan tenaga mesin dan adanya peralihan dari perekonomian yang berbasis pertanian menuju perekonomian yang berbasis manufaktur, istilah Buen Vivir dalam konteks kasus Mirador di Ekuador (van Teijlingen \& Hogenboom, 2016) atau hidup berdampingan dengan alam, muncul dalam konteks konflik air di Bolivia

Berdasarkan hal tersebut menyebabkan peralihan besar-besaran dari masyarakat desa menuju ke kota dan akhirnya menyebabkan pembengkakan jumlah populasi di daerah kota, revolusi industri sendiri menandai dimulainya era pertumbuhan ekonomi kapitalis dan revolusi industri sendiri dianggap sebagai peristiwa paling penting yang pernah terjadi dalam sejarah kemanusiaan.(Chan, Kahn, Scott, \& Vetere, 2007)

Salah satu munculnya problem industrialisasi yang saat ini telah menjamur dan menjadi tonggak perekonomian suatu negara adalah polusi. Polusi sendiri dapat diartikan sebagai output dari perusahaan yang mengakibatkan kerusakan lingkungan. polusi sendiri terbagi menjadi polusi udara, air dan polusi tanah yang diakibatkan oleh zat-zat yang diproduksi oleh suatu perusahaan bersifat merusak, salah satu yang paling marak adalah polusi melalui air. Belum lagi terkait permasalahan perubahan iklim yang saat ini menjadi isu dunia, peran sosiolog dalam melihat perubahan 
iklim (Ciplet et al., 2015), sama dengan yang disampaikan oleh (Bhatasara, 2015) melihat bahwa peran masyarakat lebih diutamakan dalam melihat perkembangan perubahan iklim yang saat ini terjadi.

Polusi melalui air ini langsung memberikan dampak yang cepat terhadap ekosistem sungai, hal ini juga berkaitan dengan keadaan tanah. Yang dimaksud adalah air yang tercemar tadi teresap ke dalam tanah yang menyebabkan keadaan tanah tersebut tidak subur, hal ini juga berdampak terhadap kehidupan sosial manusia, hidup masyarakat sekitar daerah tercemar menjadi tidak tenang, kesehatan masyarakat sekitar tidak terjaga dengan baik.

Pencemaran air juga terjadi di Kota Malang, terutama di daerah aliran sungai yang berada di daerah Ciptomulyo Sukun Kota Malang. sungai ini telah tercemar oleh limbah perusahaan kulit yang di mana terdapat 2 perusahaan kulit yang satu bernama PT Usaha Loka dan yang kedua bernama PT Kasin. Menurut sumber berita kedua PT tersebut membuang limbah di kali badek sebelum memaksimalkan pengolahan limbah yang dilakukan oleh pihak perusahaan tersebut.

Berdasarkan fakta lapangan yang menyebutkan bahwa PT Kasin dan PT Usaha Loka melakukan pencemaran terhadap sungai yang mengalir tepat di tengah-tengah pemukiman masyarakat ini berasal dari limbah hasil produksi penyamakan kulit, inti dari permasalahan ini adalah adanya kegiatan pencemaran lingkungan khususnya daerah aliran sungai oleh kedua pabrik terrsebut. Kegelisahan masyarakat sekitar sungai Badek atau sungai bau dalam Bahasa Indonesia,sungai ini merupakan anak sungai Brantas yang mayoritas mengalir di daerah-daerah di Jawa Timur, dahulu sungai ini belum mendapat julukan sungai Badek,karena sumbernya masih asri dan jernih, tetapi setelah terjadsi pencemaran hasil limbah pabrik sungai yang awalnya jernih menjadi tercemar dan menimbulkan bau yang luar biasa. Warga setempat saat ini sudah dipaksa menghirup udara yang kurang baik bagi kesehatan mereka selama kurang lebih 34 Tahun.

PT Usaha Loka berdiri sekitar 37 Tahun terlebih dahulu sebelum PT Kasin yang beroperasi tepatnya 34 Tahun atau selisih 3 Tahun berdirinya dengan PT Usaha Loka, yang dirasakan masyarakat setiap harinya telah 
mencapai pada fase mengganggu baik terganggu dari segi fisik maupun dari segi non fisik, dengan adanya perusahaan yang melakukan pembuangan limbah yang kurang tertata dengan baik mampu memberikan dampak yang sangat terasa pada masyarakat sekitar sungai tersebut. Bagi produsen penghasil limbah membuang limbah secara langsung tanpa memaksimalkan IPAL yang ada akan berdampak positif pada segi anggaran, tetapi hal ini jauh berbeda dari konteks lingkungan, karena akan berdampak langsung pada kerusakan lingkungan dan kesehatan masyarakat.

Kepala BLH Kota Malang menyatakan bahwa, hasil dari uji laboratorium itu menyebutkan bahwa hasil uji laboratorium kedua perusahaan tersebut sudah keluar, dengan hasil yang menyebutkan bahwa hasil air limbah perusahaan itu positif mencemari sungai badek, hal ini sungguh membuat lingkungan sekitar Malang khususnya sungai- sungai yang menjadi urat nadi satu kota menjadi tercemar

Masyarakat sekitar yang sampai saat ini mengetahui bahwa keberadaan kedua perusahaan tersebut telah mencemari sungai sekitar tempat mereka bahkan bukan hanya mencemari secara keadaan airnya tetapi juga membuat bau yang tidak sedap bagi masyarakat sekitar sungai badekdan hal ini yang dipertajam dengan hasil uji laboratorium BLH kota Malang, masyarakat pun ingin perusahaan tersebut segera mengelola limbah hasil produksi pihak mereka dengan efektif sebelum di buang ke sungai Kesabaran warga Ciptomulyo, Sukun, Kota Malang dengan keberadaan limbah perusahaan kulit yang menimbulkan bau tidak sedap nampaknya sudah habis. Mereka merasa selama bertahun-tahun menjadi korban perusahaan milik PT Kasin dan PT Usaha Loka itu. Karena setiap hari menghirup aroma tak sedap, sungai badek yang harusnya bisa dimanfaatkan warga ikut tercemar.

Sudah puluhan tahun, warga Kelurahan Ciptomulyo merasakan bau tidak enak dari limbah perusahaan tersebut. Berulang kali melayangkan protes, namun selalu tidak ada penyelesaian dari perusahaan, apa yang telah dialami oleh warga Kelurahan Ciptomulyo selama ini tidak hanya berdampak terhadap kondisi lingkungan tempat mereka tinggal saja, melainkan telah berdampak pada kehidupan sosial mereka, hal ini 
menunjukkan bahwa apa yang telah dilakukan oleh 2 perusahaan kulit tersebut telah kemunculan permasalahan dari berbagai segi kehidupan, dalam kehidupan sosial masyarakat mengalami apa yang dinamakan dengan senasib sepenanggungan yaitu sebuah keadaan yang masyarakat alami antara individu satu dan yang lain sama.

Kejadian pencemaran lingkungan yang tak kunjung henti inilah yang membuat masyarakat sekitar geram oleh sikap industri tersebut, berawal pada tahun 2001 muncul gerakan masyarakat yang diberi nama FKPL (Forum Komunikasi Pecinta Lingkungan) yang di ketuai oleh Bapak Hariyadi motto gerakan awal ini adalah "jangan sampai kita masuk angin", dalam artian jangan sampai ada anggota kita yang di suap oleh pihak perusahaan kulit tersebut inti munculnya gerakan pertama ini merupakan salah satu bentuk protes masyarakat kepada pemerintah yang seakan membiarkan saja urusan pencemaran lingkungan ini terjadi.

Sayangnya selama gerakan ini terbentuk belum ada hal-hal signifikan seperti adanya perubahan atau adanya aturan yang di hasilkan agar perusahaan lebih memperhatikan IPAL yang dimiliki, cuma sebatas melawan dengan cara yang halus, masyarakat belum sampai ke ranah pemerintah hanya sekedar rapat-rapat biasa. dan setelah gerakan FKPL (Forum Komunikasi Pecinta Lingkungan) ini berjalan kurang lebih 3 bulan, perusahaan tersebut berhasil membaca gerak-gerik gerakan FKPL yang mulai dianggap meresahkan kegiatan produksi perusahaan tersebut, dan akhirnya motto gerakan pertama yang memiliki arti jangan sampai kita di suap, hal tersebut malah di langgar oleh beberapa anggota FKPL tersebut, seperti sang ketua gerakan tersebut yaitu Bapak Hariyadi sendiri yang di bantu dalam bentuk beasiswa untuk anak-anaknya..

Berdasarkan keadaan internal gerakan yang mudah ditembus oleh perusahaan, maka tidak heran bila hal tersebut yaitu masalah diberi uang sangat mudah sekali untuk di lakukan, uang merupakan suatu alat yang sangat mudah untuk menggoyahkan individu dalam hal ini ketua gerakan FKPL sendiri yang merasakan, apabila ditanya lagi bahkan sampai perusahaan nekat memecah belah masyarakat yang satu dengan yang lain. 
Gerakan yang kedua ini berawal pada awal tahun 2014 yang berakar pada inisiatif salah satu warga pendatang yang bernama Mas Rozi, dari inisiatif Mas Rozi yang merupakan warga RT 12 inilah kasus pencemaran lingkungan di daerah Kelurahan Ciptomulyo ini sedikit demi sedikit diangkat dan berharap permasalahan ini terselesaikan dengan baik, dan langsung membentuk gerakan yang baru atau gerakan yang kedua dengan nama AMCPL (Aliansi Masyarakat Ciptomulyo Peduli Lingkungan) dan di kepalai oleh Bapak Imam "Samba" sendiri, kegiatan pertama yang dilakukan oleh gerakan AMCPL adalah menemui komisi A dan komisi D mereka akan menyerahkan laporan mengenai pencemaran limbah di sungai tersebutdengan bantuan Mas Rofi;i tadi yang merupakan salah satu anggota Fraksi PAN membantu masyarakat untuk mengangkat kembali kasus pencemaran lingkungan ini teringat yang sebelumnya belum dilakukan oleh gerakan pertama.

Dampak perpecahan yang ditimbulkan oleh gerakan pertama dalam masyarakat terbentuk masyarakat yang pro dan masyarakat yang kontra terhadap munculnya gerakan kedua yang diinisiasi oleh Mas Rozi tersebut, hal ini terbukti pada saat melakukan rapat koordinasi jumlah warga yang datang hanya sedikit, padahal sebelumnya telah beredar sebuah form yang berisikan nama dan tanda tangan para warga untuk mendukung gerakan perlawanan ini kembali, dampak sosial dengan terpecahnya masyarakat menjadi topik yang bagus di dengar oleh pemilik perusahaan itu sendiri, yang termasuk di sini adalah gerakan kedua itu sendiri, dalam aspek sosial gerakan tersebut minim akan dorongan,minim akan dukungan dari warga asal sendiri, hal ini dikarenakan masyarakat sudah menaruh curiga bahwa gerakan kedua ini akan berakhir sama dengan gerakan pertama.

Dampak dari munculnya gerakan pertama memunculkan 2 aliran yang berada di dalam tubuh masyarakat itu sendiri, yaitu aliran yang pro dikarenakan diberi jabatan fungsional oleh perusahaan,warga yang demo dan melawan perusahaan diangkat menjadi karyawan perusahaan hingga ada yang diberi beasiswa oleh perusahaan kulit tersebut, beberapa hal ini muncul karena perusahaan melakukan intervensi terhadap keberlanjutan gerakan sosial masyarakat ini, karena merasa keberlangsungan produksi 
perusahaan akan terhambat apabila gerakan sosial masyarakat ini bertumbuh kembang maka perusahaan melakukan langkah-langkah intervensi dengan cara pendekatan yang halus atau dalam bahasa umumnya perusahaan melakukan lobi-lobi terhadap kepala gerakan tersebut untuk segera memberhentikan aktivitas protes terhadap perusahaan kulit tersebut.

Sedangkan aliran yang kedua yaitu aliran yang tetap bersikukuh untuk melawan apa yang telah dilakukan oleh perusahaan kulit tersebut dengan kata lain aliran yang kontra terhadap apa yang dilakukan oleh perusahaan,hal ini bermunculan karena kedua perusahaan kulit tersebut melakukan aksi pencemaran lingkungan melalui pembuangan limbah hasil produksi perusahaan tanpa memaksimalkan sistem IPAL yang dimiliki,alasan gerakan yang kontra dengan perusahaan ini adalah perusahaan melanggar UU Lingkungan Hidup,masyarakat sekitar ingin bau yang dihasilkan melalui proses pencemaran ini akan sedikit demi sedikit hilang,perusahaan bertindak curang dengan tidak memaksimalkan IPAL yang dimiliki, maka gerakan ini bisa saja disebut sebagai genuine movement.

Teori yang peneliti gunakan adalah teori gerakan sosial menurut Macionis (Sukmana:2016,26) dapat disimpulkan bahwa terdapat 4 tahapan dalam proses gerakan sosial, yakni: Emergence (tahap kemunculan) gerakan sosial didorong oleh suatu persepsi bahwa segalanya tidak baik. Beberapa gerakan perempuan dan hak asasi sipil, misalnya muncul karena penyebaran ketidakpuasan. Sementara gerakan sosial yang lain muncul sebagai kesadaran yang dipelopori oleh kelompok-kelompok kecil tentang beberapa isu tertentu, Coalescene ( tahap penggabungan) setelah kemunculan, suatu gerakan sosial harus mendefinisikan sendiri dan mengembangkan strategi untuk menuju publik. Pemimpin harus menentukan kebijakan, memutuskan suatu taktik, membangun moral, dan melakukan rekrutmen keanggotaan baru. Dalam hal ini gerakan mungkin terlibat dalam tindakan kolektif seperti demonstrasi untuk menarik perhatian media massa dan perhatian publik. Gerakan juga dimungkinkan membentuk aliansi dengan organisasi yang lainnya untuk mendapatkan sumber daya yang diperlukan, Bureaucratization (Tahap birokrasi) agar menjadi sebuah kekuatan politik, suatu gerakan sosial 
harus memiliki sifat-sifat birokrasi, dengan demikian gerakan akan menjadi mapan dan Decline (tahap penurunan) pada akhirnya, suatu gerakan sosial akan kehilangan pengaruh-pengaruhnya.

Berdasarkan latar belakang diatas, maka rumusan masalah yang peneliti ambil adalah bagaimana dinamika gerakan sosial dalam menentang limbah perusahaan kulit? Tujuan penelitian ini adalah untuk mendeskripsikan dinamika gerakan sosial dalam menentang limbah perusahaan kulit.

Metode penelitian yang digunakan adalah Dalam penelitian ini peneliti menggunakan pendekatan kualitatif dengan menggunakan jenis penelitian studi kasus. Studi kasus merupakan strategi penelitian di mana di dalamnya peneliti menyelidiki secara cermat suatu program, peristiwa, aktivitas, proses suatu individu. Kasus-kasus dibatasi oleh waktu dan aktivitas, dan peneliti mengumpulkan informasi secara lengkap dengan menggunakan berbagai prosedur pengumpulan data berdasarkan waktu yang telah ditentukan. Stake (Creswell:2014,20).

Robert K Yin $(2011,1)$ secara umum studi kasus merupakan strategi yang lebih cocok bila pokok pertanyaan suatu penelitian berkenaan dengan how atau why, bila peneliti hanya memiliki sedikit peluang untuk mengontrol peristiwa-peristiwa yang akan diselidiki, dan bilamana fokus penelitiannya terletak pada fenomena kontemporer (masa kini) di dalam konteks kehidupan nyata.

Ada tiga langkah dasar dalam menggunakan studi kasus: pengumpulan data, analisis, dan menulis. Hal pertama yang harus diingat tentang penggunaan studi kasus adalah bahwa kasus ini harus memiliki masalah bagi para peneliti untuk memecahkannya. Kasus ini harus memiliki informasi yang cukup di dalamnya. Di mana peneliti dapat memahami apa masalahnya dan memungkinkan dikembangkan suatu kerangka analisis untuk memecahkan misteri kasus tersebut (Bungin:2011,132). 


\section{B. Diskusi}

\section{Isu Polusi Udara dan Air (Gerakan Pertama Tahun 2001)}

Masalah pencemaran air dari berbagai industri yang proses industrinya menggunakan zat-zat kimia, kini semakin meningkat di wilayah kota Malang ini. Pencemaran tersebut dapat terjadi terutama yang diakibatkan dari pembuangan limbah cair perusahaan yang tidak menangani bahan buangannya secara benar. Jika bahan buangan dari industri langsung dibuang ke luar perusahaan tanpa melalui proses pengolahan yang tepat, maka akan terjadi pencemaran air yang akan membahayakan kelangsungan hidup dan dapat pula menimbulkan kerugian material yang tidak sedikit jumlahnya. Untuk menghindari permasalahan tersebut diperlukan pencegahan dan penanggulangan secara khusus dan serius oleh berbagai pihak. Dalam hal ini pemerintah telah melaksanakan kebijakan pembangunan berwawasan lingkungan. Kebijaksanaan ini tidak saja diberlakukan terhadap perusahaan industri yang akan berdiri tetapi juga perusahaan industri yang telah berdiri.

Dalam hal ini permasalahan muncul dikarenakan adanya pencemaran yang dilakukan oleh PT Kasin dan PT Usaha Loka di sungai yang mengalir tepat di tengah-tengah pemukiman warga, pencemaran yang seakan-akan dibiarkan oleh pemerintah dan sudah hampir 34 tahun warga sekitar Kelurahan Ciptomulyo dipaksa untuk menghirup udara yang tercemar dan buruk bagi kesehatan, bau yang berasal dari limbah proses penyamakan kulit. PT Usaha Loka sendiri mempunyai 2 macam produksi yang pertama adalah pengolahan kulit dan yang kedua adalah pengolahan kayu, dari 2 macam produksi yang di hasilkan, pengolahan kulitlah yang memiliki limbah yang begitu dahsyat pencemarannya di bandingkan dengan limbah hasil produksi kayu.

PT KASIN LEATHER didirikan oleh Ichwan Zacharia sejak 1941 di kawasan kampung KASIN, di tepi sungai yang membelah kota Malang. Karena perluasan industri, oleh pemerintah ditawarkan untuk pindah ke kawasan industri di kelurahan Ciptomulyo. 
Sejak April 1951, PT Kasin dipindah, diperluas dan beroperasi dengan penambahan sarana untuk menjadi exportir. Pada tahun 1975, Paul I.Zacharia melanjutkan usaha sampai saat ini.

Berdasarkan kasusnya, PT Usaha Loka dan PT Kasin melakukan penyalahgunaan terhadap kontrol limbah. Perusahaan tersebut terbukti mencemari Kali Badek di Kelurahan Ciptomulyo, Kecamatan Sukun, Kota Malang. Hal tersebut terbukti dari hasil uji laboratorium limbah kedua perusahaan tersebut positif mencemari sungai yaitu melebihi baku mutu.

Perusahaan tersebut seharusnya diberi tindakan tegas, akan tetapi Badan Lingkungan Hidup Kota Malang tidak menindaknya karena alasan yang kurang masuk akal yaitu karena perusahaan tersebut akan dibina nantinya dengan didampingi tenaga ahli. Masalah ini harus ditanggapi serius dan cepat dalam melaukan penanganannya, jika tidak, maka akan merugikan masayarakat yang tinggal disekitar Kali Badek. Masalah yang biasanya dialami yaitu seperti bau menyengat dari limbah, air kali maupun air serapan kali yang biasanya dipakai warga menjadi kotor, menimbulkan bibit penyakit yang dihasilkan dari limbah tersebut, merusak lingkungan disekitar Kali Badek.

\section{Terjadi Diskursus Tentang Pencemaran Limbah (Gerakan Pertama} Tahun 2001)

Berdasarkan permasalahan limbah di atas gerakan perlawanan masyarakat yang pertama itu terbentuk pada tahun 2001, Kejadian pencemaran lingkungan yang tak kunjung henti inilah yang membuat masyarakat sekitar geram oleh sikap industri tersebut, muncul gerakan masyarakat yang diberi nama FKPL (Forum Komunikasi Pecinta Lingkungan) yang diketuai oleh Bapak Hariyadi motto gerakan awal ini adalah "jangan ada dusta di antara kita dan jangan sampai kita masuk angin", dalam artian jangan sampai ada anggota kita yang menerima suap oleh pihak perusahaan kulit tersebut inti munculnya gerakan pertama ini merupakan salah satu bentuk protes masyarakat kepada pemerintah yang seakan membiarkan saja urusan pencemaran lingkungan ini terjadi. 
Sayangnya selama gerakan ini terbentuk belum ada hal-hal signifikan seperti adanya perubahan atau adanya aturan yang dihasilkan agar perusahaan lebih memperhatikan IPAL yang, namun pada gerakan pertama masyarakat berhasil duduk bersama dengan perusahaan yang menghasilkan pembangunan pipa-pipa guna mengalirkan limbah tanpa langsung ke sungai

\section{Impact Gerakan Pertama Terhadap Masyarakat (Gerakan Pertama}

\section{Tahun 2001)}

Dan setelah gerakan FKPL (Forum Komunikasi Pecinta Lingkungan) ini berjalan kurang lebih 3 bulan, perusahaan tersebut berhasil membaca gerak-gerik gerakan FKPL yang mulai dianggap meresahkan kegiatan produksi perusahaan tersebut, dan akhirnya motto gerakan pertama yang memiliki arti jangan sampai kita masuk angin (terkena suap), hal tersebut malah dilanggar oleh beberapa anggota FKPL tersebut.

Dengan keadaan internal gerakan yang mudah ditembus oleh perusahaan, maka tidak heran bila hal tersebut yaitu masalah diberi uang sangat mudah sekali untuk dilakukan, uang merupakan suatu alat yang sangat mudah untuk menggoyahkan individu dalam hal ini yaitu ketua gerakan FKPL sendiri yang merasakan, apabila ditanya lagi bahkan sampai perusahaan nekat memecah belah masyarakat yang satu dengan yang lain, hal ini juga tidak terlalu jauh dengan yang namanya uang tersebut, hasil temuan lapangan bahwa masyarakat yang berada di seberang rel kereta api yaitu masyarakat RW 02 telah dipengaruhi oleh perusahaan agar para masyarakat di sana pro dengan keberadaan kedua perusahaan tersebut, dengan berbagai cara mulai diberi uang, anak-anak mereka di sekolahkan, hingga diangkat menjadi salah satu karyawan perusahaan tersebut.

\section{Pergerakan Masyarakat II (Gerakan Kedua Tahun 2014)}

Menurut informan yang peneliti temui di lapangan terkait masalah pencemaran di Kelurahan Ciptomulyo sendiri sudah termasuk permasalahan klasik hal ini merujuk pada mulai awal periode kepemimpinan Peni Suparto permasalahan ini sudah diangkat dan tetap saja tidak menemui titik terang hingga beliau menjabat sampai dua kali periode yaitu 10 Tahun menjabat 
dan berakhir pada Tahun 2012 masalah ini tak kunjung selesai juga, hingga akhirnya pada kepemimpinan Moch Anton dengan slogannya peduli wong cilik masyarakat Kelurahan Ciptomulyo kembali mengangkat kasus ini dengan.

Gerakan yang kedua ini berawal pada awal tahun 2014 yang berakar pada inisiatif salah satu warga pendatang, Dari inisiatif Mas Rozi selaku pendatang yang merupakan warga RT 12 inilah kasus pencemaran lingkungan didaerah Kelurahan Ciptomulyo ini sedikit demi sedikit diangkat dan berharap permasalahan ini terselesaikan dengan baik, dan langsung membentuk gerakan yang baru atau gerakan yang kedua dengan nama AMCPL (Aliansi Masyarakat Ciptomulyo Peduli Lingkungan) dan diketuai oleh Abah Imam "Samba" sendiri, kegiatan pertama yang dilakukan oleh gerakan AMCPL adalah menemui komisi A dan komisi D mereka akan menyerahkan laporan mengenai pencemaran limbah di sungai tersebut dengan bantuan Mas Rofi;i untuk mengangkat kembali kasus pencemaran lingkungan ini.

Tepatnya pada Tanggal 21 - Januari - 2014 Tiga orang perwakilan warga dari $4 \mathrm{RT}$ 4, 9, 12, dan 13 yang berada di RW 01 Kelurahan Ciptomulyo ini meminta perlindungan dewan karena perusakan lingkungan dari kedua perusahaan tersebut sangat meresahkan warga. Dalam kunjungannya ke Komisi A DPRD Abah Imam "Samba" selaku ketua RT 01 RW 06 menjelaskan, sudah puluhan tahun, warga Ciptomulyo merasakan bau tidak enak dari limbah perusahaan tersebut. Berulang kali melayangkan protes, namun selalu tidak ada penyelesaian dari perusahaan."Kalau tidak percaya lihat sendiri ke sungainya, baunya sama sekali tidak enak,".

Dari pengaduan pertama kali ke Komisi A tersebut, keluhan warga ditanggapi dengan janji pemerintah Kota Malang berjanji untuk mengawal warga Kelurahan Ciptomulyo dalam menyelesaikan kasus pencemaran lingkungan yang dilakukan oleh kedua perusahaan tersebut yang telah cukup lama terjadi, dengan bantuan inilah masyarakat Kelurahan Ciptomulyo tidak perlu menunggu lama segera dikawal menuju BLH (Badan Lingkungan Hidup) Kota Malang untuk mendalami kasus ini, tepatnya pada tanggal 24Februari- 2014, Badan Lingkungan Hidup Kota Malang, Jawa Timur, 
mengeluarkan surat teguran terhadap dua perusahaan kulit yang diduga mencemari lingkungan. PT Usaha Loka dan PT Kasin terbukti mencemari Kali Badek di Kelurahan Ciptomulyo, Kecamatan Sukun, Kota Malang. "Hasil uji laboratorium menunjukkan (limbah kedua perusahaan itu) positif mencemari sungai," kata Kepala Badan Lingkungan Kota Malang Bapak Nuzul Nurcahyo,

Bapak Nuzul mendesak kedua perusahaan pengolah kulit itu untuk mengelola air limbah secara maksimal. Tujuannya mencegah pencemaran sungai yang mengalir di wilayah Kota Malang. Uji laboratorium atas air limbah dilakukan dua kali. Kedua hasil uji laboratorium menunjukkan air limbah yang dibuang ke sungai melebihi baku mutu. Namun Badan Lingkungan Hidup tak menindak tegas kedua perusahaan pengolah kulit tersebut, seperti menghentikan izin operasional ataupun menutup perusahaan. Alasannya kedua perusahaan akan dibina. Perusahaan pencemar lingkungan itu akan didampingi tenaga ahli untuk mengolah limbah.

\section{Pergerakan Masyarakat Tahap II(Gerakan Kedua Tahun 2014 Proses}

\section{Advokasi)}

Seperti pada waktu advokasi pada tanggal 1 September 2014 yang dilakukan di gedung DPRD Kota Malang, ini merupakan salah satu bentuk keseriusan pemerintah dalam menanggapi masalah ini dengan mendatangkan pengacara dari LBH yang bernama mas Wiwid Tuhu, di mana pada advokasi tersebut dilakukan diskusi antara pihak perwakilan Masyarakat Kelurahan Ciptomulyo ,LBH, dan pemerintah Kota Malang untuk mencari solusi agar permasalahan ini cepat selesai, apalagi hal ini juga didukung dengan media lokal setempat yaitu Koran Radar Malang dalam hal ini mempunyai andil mengangkat kembali kasus Pencemaran di daerah Ciptomulyo intens selama beberapa hari.

Pembicaraan berawal mulai dari sejarah hingga keluhan yang dialami masyarakat, dengan berbagai pendapat Mas Wiwid selaku dari LBH menerangkan kepada masyarakat jangan sampai bertindak anarkis dikarenakan hal itu dapat berdampak langsung kepada masyarakat apabila 
perusahaan tersebut melaporkan balik ke pihak yang berwajib mengenai tindakan anarkis tersebut seperti menutup saluran pembuangan limbah perusahaan, Mas Wiwid juga menjelaskan mengenai IMB (Izin Mendirikan Bangunan) yang dimiliki oleh perusahaan tersebut tidak dapat di ganggu gugat lagi dikarenakan perusahaan tersebut mulai ada sebelum adanya pemukiman masyarakat yang muncul di daerah sekitar tempat perusahaan tersebut beroperasi dan mas Wiwid juga menjelaskan mengenai pencemaran yang dialami masyarakat sekarang dengan pencemaran yang dirasakan oleh masyarakat dahulu sangat berbeda namun pada intinya sama tutur mas Wiwid Tuhu selaku pengacara yang siap membantu masyarakat Kelurahan Ciptomulyo dalam menyelesaikan permasalahan ini.

Track record Mas Wiwid sendiri terbilang cukup bagus dalam menyelesaikan sengketa beliau menyelesaikan kasus pencemaran lingkungan di daerah Rembang dll, merasa mendapat angin segar masyarakat pun bersemangat dalam hal ini mas Rozi dan Bapak Imam "Samba" merasa on fire lagi untuk meneruskan gerakan pertama yang dahulu telah masuk angin dikarenakan ada oknum yang di suap oleh perusahaan yang membuat gerakan pertama terhenti di tengah jalan.

Namun setelah mengalami hal tersebut dari warga sekarang baik Mas Rozi maupun Abah Imam "Samba" kembali menggeluti bidang yang dahulu mereka tinggalkan dan hanya menunggu dari keputusan pemerintah terhadap perusahaan, yang dulunya pemerintah memberikan 3 opsi pilihan tersebut. Mas Rozi dan Abah Imam "Samba" ikut pula menunggu hasil dari ke 3 opsi tersebut, namun Abah Imam menambahkan kami tidak hanya tinggal diam saja mas kami akan tetap memantau perusahaan tersebut dalam hal ini memantau aktivitas pembuangan limbah perusahaan dan intensitas bau yang dihasilkan baik di malam hari maupun di pagi hari saat banyak aktivitas warga di luar rumah.

\section{Impact Gerakan II Terhadap Masyarakat (Gerakan Kedua Tahun 2014)}

Namun masih saja terdapat permasalahan yang khususnya di alami oleh mas rozi dan Bapak Imam. Warga sekitar rumah beliau dirasa acuh dan tidak mau untuk bergerak bersama-sama beliau hal ini 
dikarenakan warga sekitar merasa kapok dengan gerakan pertama yang dahulu sempat mereka dukung namun pada akhirnya tanpa membawa hasil.

Dari pengalaman generasi pertama yang dirasakan oleh warga sekitar hal ini menjadi sulit bagi Mas Rozi dan Abah Imam "Samba" untuk menyatukan warga kembali guna mendukung aksi mereka.

\section{Kesimpulan}

Berdasarkan hasil penelitian yang telah dilakukan oleh peneliti tentang dinamika gerakan sosial dalam menentang pembuangan limbah perusahaan kulit di Kelurahan Ciptomulyo Kota Malang, dapat disimpulkan sebagai berikut:

\section{Dinamika Gerakan}

Dinamika gerakan terjadi pada dua tahap yaitu pada tahun 2001 dan 2014. Pada tahun 2001:

1. pada saat dirasa butuh untuk dibentuknya gerakan masyarakat yang berguna untuk memberikan kesadaran terhadap masyarakat bahwa lingkungan mereka telah tercemar oleh limbah perusahaan kulit melalui proses penyamakan kulit yang menyebabkan sungai di sekitar tempat tinggal masyarakat terjadi polusi udara dan air yang berasal dari proses pengolahan air limbah milik kedua perusahaan yang tidak berjalan dengan baik hal ini menjadikan sungai yang mengalir tepat di wilayah Ciptomulyo menjadi bau dan tercemar.

2. hal ini juga diiringi oleh adanya tokoh masyarakat yang siap membela kepentingan masyarakat. selain faktor memang dibutuhkannya gerakan untuk melawan perusahaan.

3. proses pasang dinamika gerakan tersebut juga dipicu oleh tuntutan masyarakat sekitar agar perusahaan banyak merekrut warga sekitar untuk menjadi karyawan perusahaan, karena selama ini perusahaan kulit tersebut mengambail karyawan dari luar daerah Ciptomulyo sendiri. 


\section{Selanjutnya proses pasang surut dinamika gerakan pada tahun}

\section{4:}

1. gerakan terjadi pada saat Abah Anton terpilih sebagai walikota Malang pada tahun 2014 ,beliau mempunyai semboyan "peduli uwong cilik" (Peduli Orang Kecil), dengan kata lain ada momentum di mana masyarakat Kelurahan Ciptomulyo untuk kembali menghidupkan gerakan masyarakatnya untuk kembali mengangkat permasalahan lingkungan yang telah lama menghantui warga masyarakat, momentum ini dirasa tepat dengan diiringi semboyan walikota Malang yang baru.

Sedangkan dalam proses surutnya dinamika gerakan masyarakat hal ini diiringi oleh kepentingan pribadi yang mempengaruhi tumbuhnya gerakan tersebut untuk tetap solid, dalam bahasa lain ada kepentingan dibalik munculnya gerakan masyarakat tersebut, kepentingan atau Intertest tersebutlah yang menjadikan gerakan masyarakat tersebut pecah dan mengalami proses surut. Bukan berhenti dari itu saja faktor surutnya gerakan juga disebabkan oleh kekuatan yang dimiliki oleh perusahaan untuk menyewa preman-preman guna menakut-nakuti masyarakat yang ingin melawan perusahaan, hal ini sekali lagi menegaskan bahwa siapa yang punya modal bisa menguasi dan bermain seenaknya.

Dalam proses tersebut tidak hanya faktor negatif saja yang membuat gerakan ini mengalami surut, juga terdapat faktor positif yang membuat gerakan tersebut surut diantara lain terjadinya kesepakatan dari pihak perusahaan untuk meninjau kembali proses Instalasi pengolahan Air limbah (IPAL) yang dimiliki oleh perusahaan, karena hal ini merupakan yang dirasa oleh masyarakat belum optimal yang dilakukan oleh perusahaan.

Selain berasal dari pihak perusahaan saja permasalahan surutnya gerakan masyarakat ini, faktor kepercayaan masyarakat terhadap gerakan juga mempengaruhi keberlangsungan gerakan masyarakat untuk berdiri dan kembali memberikan suara-suara perlawanan terhadap perusahaan kulit tersebut, kehilangan kepercayaan dari masyarakat, masyarakat yang enggan untuk mendukung gerakan tersebut juga memberikan dampak yang 
Dinamika Gerakan Sosial...

signifikan terhadap bagaimana surutnya gerakan masyarakat dalam melawan perusahaan.

Komunitas Vol. 11, No. 1 (2020) | 95 


\section{Referensi}

Andersson, J., \& Westholm, E. (2019). Closing the Future: Environmental Research and the Management of Conflicting Future Value Orders. Science Technology and Human Values, 44(2), 237-262. https://doi.org/10.1177/0162243918791263

Bhatasara, S. (2015). Debating sociology and climate change. Journal of Integrative Environmental Sciences, 12(3), 217-233. https://doi.org/10.1080/1943815X.2015.1108342

Chan, A., Kahn, V., Scott, C., \& Vetere, P. (2007). Bolivian Water Wars.

Ciplet, D., Roberts, T., Melathopoulos, A., Dunlap, R., Ciplet, D., Roberts, J. T., \& Change, C. (2015). Wanted: More Climate Change in Sociology; More Sociology in Climate Change ( Policy ). 145-150.

van Teijlingen, K., \& Hogenboom, B. (2016). Debating Alternative Development at the Mining Frontier: Buen Vivir and the Conflict around El Mirador Mine in Ecuador. Journal of Developing Societies, 32(4), 382-420. https://doi.org/10.1177/0169796X16667190

Bungin B.2008.Penelitian Kualitatif.Jakarta.Kencana Pranada Media Group K.Yin.R.2011.Studi Kasus Design dan Metode.Jakarta PT RajaGrafindo Persada

Sukmana.O.2016.Konsep dan Teori Gerakan Sosial.Malang: Intrans Publishing

W.Creswell.J.2013.Research Design Pendekatan Kualitatif,Kuantitatif,dan Mixed Method.Yogyakarta.Pustaka Pelajar. 